\title{
Minat Partisipasi Dalam Olahraga Ditinjau Dari Suku Bangsa Pada Siswa Di Kota Palangka Raya
}

\author{
Yudo Harvianto \\ Jurusan Pendidikan Jasmani, Kesehatan dan Rekreasi, \\ Fakultas Keguruan dan Ilmu Pendidikan, Universitas Palangka Raya, \\ Email : yudoharvianto@gmail.com
}

\begin{abstract}
Abstrak : Aspek psikologi sangat mempengaruhi terhadap kehidupan seseorang dalam menjalankan kehidupan sehari-hari. Salah satu contoh aspek psikologi yang dapat mempengaruhi kehidupan sehari-hari yaitu minat.Sehingga tidak terpisahkan antara aspek psikologi dalamberolahraga.Minat dan partisipasi berolahraga berbeda antara budaya satu dengan yang lainnya. Setiap budaya memiliki norma atau aturan masing-masing yang mengatur kehidupan sosialnya, sehingga akan menciptakan lingkungan dan karakter individu yang berbeda. Hal inilah yang menyebabkan setiap individu mempunyai ciri khas sesuai dengan budayanya.Tujuan dari penelitian ini yaitu mengkaji dan menganalisis minat partisipasi dalam olahraga ditinjau dari suku bangsa serta alasan memilih melakukan olahraga tertentu.Jenis penelitian ini menggunakan metode mixedmethods yaitu deskriptif kuantitatif dan fenomelogis kualitatif. Subjek dalam penelitian ini sebanyak 300 siswa dengan menggunakan teknik pusposive sampling yang terdiri dari siswa bersuku Dayak, Banjar dan Jawa. Analisis data yang digunakan adalah analisis deskriptif kuantitatif dan analisis data model interaktif.Berdasarkan hasil penelitian menunjukkan bahwa (1) Siswa yang bersuku Dayak lebih menyukai berpartisipasi dalam olahraga bolavoli.Selain itu renang merupakan olahraga rutin dalam sehari-hari karena tempat tinggal mereka yang berada di pinggiran sungai, (2) Siswa yang bersuku Banjar lebih menyukai berpartisipasi dalam olahraga bulutangkis.Karakter suku Banjar yang agamis menjadikan mereka juga suka terhadap olahraga yang ada unsur religius atau rohaninya yaitu kesenian beladiri, (3) Siswa yang bersuku Jawa lebih menyukai berpartisipasi dalam olahraga sepakbola. Selain itu olahraga pencak silat juga disukai, sebab menurut mereka olahraga tersebut dapat dijadikan sebagai pegangan dan modal untuk melindungi diri sendiri dari kejahatan orang lain.
\end{abstract}

Kata kunci : Minat Partisipasi, Olahraga, Suku Bangsa

\section{PENDAHULUAN}

Aspek psikologi sangat mempengaruhi terhadap kehidupan seseorang dalam menjalankan kehidupan sehari-hari.Salah satu contoh aspek psikologi yang dapat mempengaruhi kehidupan sehari-hari yaitu minat. Begitu juga dalam olahraga, adanya keeratan antara aspek psikologi dan juga olahraga. Seakan-akan tidak bisa terpisahkan antara aspek psikologi dengan olahraga.Hal ini didasari dari sebuah pemikiran bahwa olahraga merupakan suatu aktivitas dan tingkah laku untuk mencapai suatu tujuan tertentu.Olahraga bertujuan untuk menjaga kesehatan, kebugaran tubuh dan prestasi.Peran minat berpartisipasi dalam berolahraga sangat penting untuk mengetahui seberapa besar keterlibatan seseorang dalam aktivitas olahraga.

Setiap manusia merupakan individu yang memiliki keunikan, terlebih apabila individu tersebut berada dalam komunitas kelompok suku yang berbeda-beda.Selain hal tersebut, setiap manusia memiliki bakat dan kebiasaan tersendiri serta latar belakang yang dapat mempengaruhi secara khas pada dirinya. Sejalan dengan keanekaragaman itulah minat berpartisipasi dalam berolahraga setiap individu tidak sama. Sehingga setiap individu memiliki minat yang berbeda sesuai dengan apa yang mereka pikirkan.

Menurut Gould dan Petlickoff (dalam Maksum, 2011)bahwa keinginan seseorang dalam berpartisipasi dalam berolahraga mulai dari (1)ingin mendapat sebuah kesenangan 
demi kepuasantersendiri,(2) mendapatkan kepercayaan diri,(3)mendapatkan hubungan sosial dengan teman baru (4) memperoleh hal-hal baru sebagai pengalaman, (5) mendapatkan sebuah kesuksesan, dan (6) kondisi fisik yang bugar.Sedangkan Slameto (2010) memberikan gambaran bahwa minat yang besar cenderung menghasilkan prestasi yang tinggi, sebaliknya jika minat yang kurang menghasilkan prestasi yang rendah.

Begitu juga dalam penelitan yang dilakukan oleh Lages dkk (2007) menunjukkan bahwa minat merupakan pengaruh utama bagi individu untuk meraih yang dicita-citakan. Teori ini dikuatkan pula oleh penelitian yang dilakukan oleh Zhu dkk (2009) menjelaskan bahwa minat merupakan sumber motivasi individu dalam meraih sesuatu yang diinginkan.Sedangkan Subramaniam (2009) mengatakan bahwa minat merupakan peranan penting dalam meningkatkan prestasi dan motivasi.

Minat dan partisipasi berolahraga berbeda antara budaya satu dengan yang lainnya. Setiap budaya memiliki norma atau aturan masing-masing yang mengatur kehidupan sosialnya sehingga akan menciptakan lingkungan dan karakter individu yang berbeda. Hal inilah yang menyebabkan setiap individu mempunyai ciri khas yang sesuai dengan budayanya.

Hasil penelitian Park (2006) tentang motivasi berpartisipasi dalam olahraga ketangkasan.Menunjukkan bahwa mahasiswa Amerika lebih tinggi partisipasinya dibandingkan dengan mahasiswa Korea. Begitu juga penelitian yang dilakukan Zacheus (2010) menyatakan bahwaolahragadipandangmemiliki peranan pentingdalammengajarkanbahasa dan budaya diFinlandiaserta dapat meningkatkanperasaanharga

diridankesejahteraanbagi imigran disana. Dari hasil penelitian para ahli tersebut, bahwa olahraga dan budaya memiliki hubungan yang kuat untuk saling mempengaruhi.

Indonesia adalah negara kepulauan yang memiliki banyak keragaman suku dan budaya, menyebabkan perbedaan karakter dan pengambilan keputusan/pilihan dalam segala bidang tidak bisa dihindarkan. Perbedaan ini membuat minat dan partisipasi dalam berolahraga juga akan berbeda. Dampak yang terlihat yaitu banyak cabang olahraga diminati suku tertentu tetapi tidakterlalu diminati suku lainnya.

Contoh dalam penelitian Ncube (2014) dikatakan bahwa masyarakat etnis Ndebele dan Shona di Zimbabwe mereka lebih gemar terhadap olahraga sepakbola. Sebab lagu dan nyanyian oleh para pendukung sepakbola di zimbabwe telah dikaitkan atau menggambarkan tentang identitas etnis tersebut.

Berdasarkan hasil penelitian dan pendapat para ahli diatas serta hasil observasi penulis, maka penulis tertarik untuk meneliti tentang minat partisipasi dalam olahraga ditinjau dari suku bangsa.

\section{METODE PENELITIAN}

Penelitian ini menggunakan metode mixedmethods yaitu deskriptif kuantitatif dan fenomelogis kualitatif. Penelitian ini juga menggunakan kombinasi model sequential explanatory, sebab langkah pertama menggunakan kuantitatif dan langkah kedua menggunakan kualitatif.

Subjek Penelitian. Pada penelitian ini jumah sampel bukanlah kriteria utama, namun lebih menekankan pada sumber data yang dapat memberikan informasi sesuai dengan tujuan penelitian. Subjek dalam penelitian ini adalah siswa bersuku Dayak, Banjar dan Jawa yang menempuh pendidikan Sekolah Menengah Atas (SMA) sederajat di Palangkaraya yaitu SMAN 6, MA Darul Ulum, MAN MODEL, SMKN 7, SMA Isen Mulang dan SMAN 3.

Penentuan siswa yang akan menjadi informan dalam penelitian ini dilakukan secara purposive sampling. Dalam teknik ini pengambilan subjek penelitian harus memenuhi syarat yaitu, pengambilan sampel harus didasarkan pada karakteristik tertentu yang merupakan ciri-ciri dari populasi atau didasarkan atas adanya tujuan tertentu.

Penentuan subjek penelitian didasarkan pada karakteristik sekolah yang memiliki siswa bersuku Dayak yang menempuh pendidikan yaitu SMAN 3 dan SMA Isen 
Mulang karena berada di tengah kota, suku Banjar yaitu MAN Model dan MA Darul Ulum karena berada di dekat sekitar pertokoan dan pasar swalayan, suku Jawa yaitu SMAN 6 dan SMKN 7 karena sekolah tersebut terletak di daerah transmigrasi yang mana mayoritas penduduknya bersuku Jawa.

Dari pemilihan kelompok sampel berdasarkan purposive sampling diperoleh jumlah subjek penelitian Suku Dayak sebanyak 50 siswa di SMAN 3 Palangkaraya dan= 50 siswa di SMA Isen Mulang, Suku Banjar sebanyak 50 siswa di MAN Model Palangkaraya dan sebanyak 50 siswa di MA Darul Ulum Palangkaraya, Suku Jawa sebanyak 50 siswa di SMAN 6 Palangkaraya dan sebanyak 50 siswa di SMKN 7 Palangkaraya. Sehingga jumlah subjek penelitian keseluruhan sebanyak 300 siswa.

Karakteristik atau kriteria dari subjek penelitian pada penelitian ini yaitu: (1) siswa yang menempuh pendidikan di SMA sederajat dikota Palangkaraya. (2) siswa yang kedua orang tuanya bersuku Dayak, Banjar, dan Jawa. (3) siswa yang sudah bermukim tetap di Palangkaraya minimal 3 Tahun.

Penelitian ini dilakukan di Sekolah Menengah Atas (SMA) sederajat di kota Palangkaraya yaitu SMAN 3, SMKN 7, SMAN 6, MA Darul Ulum, MAN, SMA Isen Mulang.

Teknik pengumpulan data yang digunakan dalam penelitian ini adalah kuesioner, wawancara dan Focus Group Discussion (FGD).

Instrumen dalam penelitian ini menggunakan lembaran angket atau kuesioner, panduan wawancara dan panduan FGD. (1) Lembaran kuesionerminat yang digunakan dalam penelitian ini dibuat sendiri oleh peneliti berdasarkan teori indikator minat yaitu perasaan senang, ketertarikan, perhatian, keterlibatan. Bentuk kuesioner pada penelitian ini yaitu kuesioner/angket gabungan dengan alternatif jawaban terakhir diberikan secara terbuka.Hal ini dimaksudkan untuk memberikan kesempatan kepada responden untuk menjawab secara bebas.(2) Panduan Wawancara pada penelitian ini menggunakan wawancara terstruktur secara mendalam.
Wawancara dengan menggunakan daftar pertanyaan yang telah disiapkan sebelumnya. Pertanyaan yang sama diajukan kepada semua responden, dalam kalimat dan urutan yang seragam. Siswa yang diwawancara dalam penelitian ini berjumlah 9 siswa. (3) Panduan Focus Group Discussion (FGD)atau Diskusi Kelompok Terarah adalah media bagi sekelompok orang untuk mendiskusikan satu topik tertentu secara lebih mendalam. Diskusi kelompok terarah ini mencakup 6 siswa yang tidak saling mengenal sebelumnya. Di dalamnya terdapat seorang moderator (peneliti) yang akan memandu peserta untuk mendiskusikan beberapa pertanyaan sesuai dengan topik yang dibicarakan. Karena wawancara kelompok pada dasarnya adalah teknik pengumpulan data kualitatif yang wawancaranya dipandu oleh moderator dengan cara baik secara terstruktur atau pun tidak terstruktur, bergantung pada maksud dan tujuan diskusi.

Teknik Analisis Data. Pada penelitian ini teknik yang digunakan untuk menganalisis data yaitu teknik analisis data model interaktif menurut Miles \& Huberman terdiri dari empat tahapan yang harus dilakukan.Tahapantahapan tersebut adalah :(a). pengumpulan data. Pada saat Peneliti melakukan pendekatan dan menjalin hubungan dengan informan, penyebaran angket, melakukan wawancara dan FGD, membuat catatan lapangan, maka itu merupakan proses pengumpulan data yang hasilnya adalah data yang akan diolah. Ketika peneliti telah mendapatkan data yang cukup untuk diproses dan dianalisis, maka tahap selanjutnya adalah melakukan reduksi data. (b) Tahap reduksi data. Reduksi data merupakan proses penggabungan dan penyeragaman segala bentuk data yang diperoleh menjadi satu bentuk tulisan yang akan dianalisis. Hasil dari angket, wawancara dan FGD diubah menjadi bentuk tulisan sesuai dengan formatnya masing-masing.(c) Tahap display data. Setelah semua data yang telah diformat berdasarkan instrument pengumpulan data dan telah berbentuk tulisan maka langkah selanjutnya adalah melakukan display data. Display data adalah mengolah data setengah 
jadi yang telah berbentuk tulisan ke suatu matriks kategorisasi sesuai tema-tema yang sudah dikelompokkan dan dikategorikan, serta akan memecah tema-tema tersebut ke dalam bentuk yang lebih konkrit dan sederhana yang biasa disebut subtema yang diakhiri dengan pemberia kode (coding) dari subtema tersebut sesuai dengan verbatim wawancara yang telah dilakukan.Selanjutnya yang harus dilakukan dalam tahap display data adalah mengisi kolom-kolom pada matriks ketgorisasi. Kolom matriks ketegorisasi terdiri atas tiga tahap yaitu kategori tema, sub kategori tema, dan proses pengodean. (d) Tahap penarikan kesimpulan. Kesimpulan merupakan terakhir tahapan dari serangkaian analisis data kualitatif.Pada kesimpulan ini berisi tentang uraian dari seluruh subkategorisasi tema yang tercantum pada tabel kategorisasi dan pengodean yang sudah selesai disertai dengan verbatim wawancara.Tahapan yang dilakukan pada tahap kesimpulan yaitu pertama, menguraikan subkategorisasi tema kedalam tabel kategorisasi dan pengodean disertai dengan verbatim wawancranya.Kedua, menjelaskan hasil temuan penelitian dengan menjawab pertanyaan penelitian berdasarkan aspek dari fokus penelitian.Ketiga, membuat kesimpulan dari temuan tersebut dengan memberikan penjelasan dari jawaban pertanyaan penelitian yang telah diajukan.

\section{HASIL PENELITIAN}

Dalam hasil ini, peneliti akan memaparkan sesuai dengan masing-masing sampel yaitu siswa bersuku Dayak, Banjar dan Jawa. Dengan memaparkan hasil dari jawaban kuesioner, jawaban wawancara dan FGD.

Sampel bersuku Dayak :

1. Saya senang menonton pertandingan olahraga.Jawaban Kuesioner : bola voli $32 \%$, Jawaban wawancara : Biasanya menonton pertandingan voli di balai desa dan gedung olahraga. Jawaban FGD : Sebenarnya yang paling digemari oleh mayoritas pemuda itu adalah olahraga sepak bola, karena pertandingan olahraga sepak bola mudah dicari di televisi.

2. Saya selalu mengikuti perkembangan olahraga. Jawaban kuesioner : bola voli
$42 \%$. Jawaban wawancara : mengikuti perkembangan voli karena hobi dan suka saja, sedangkan mengikuti perkembangan basket karena pemain basket keren-keren serta ingin. Jawaban FGD : mengikuti perkembangan olahraga sepak bola salah satu tujuannya karena mengagumi skill pemian idola.

3. Setiap hari saya selalu ingin melakukan olahraga. Jawaban kuesioner : bola voli $38 \%$. Jawaban wawancara : Karena bermain voli itu menyenangkan dan juga hobi. Jawaban FGD : Jawaban hampir sama dengan hasil wawancara.

4. Saya ingin menjadi atlet olahraga. Jawaban kuesioner : bola voli $30 \%$. Jawban wawancara : Ingin menjadi atlet voli karena untuk meningkatkan harga diri, meraih cita-cita, Jawaban FGD : Jawaban hampir sama dengan hasil wawancara.

5. Saya berolahraga dalam sehari minimal. Jawaban kuesioner : kurang dari 20 menit $37 \%$. Jawaban wawancara : Dalam sehari-hari waktu terbatas untuk berolahraga karena harus membagi waktu antara olahraga dengan kegiatan lain dan juga menyesuaikan kondisi fisik. Jawaban FGD : Biasanya para pemudayang berolahraga itu berolahraga lebih dari 60 menit.

6. Di lingkungan sekitar saya mayoritas melakukan aktivitas olahraga. Jawaban kuesioner : bola voli 52\%. Jawaban wawancara : Para pemuda di rumah biasanya mayoritas melakukan olahraga voli, karena hampir di setiap RT ada lapangan voli dari gotong royong masyarakat. Jawaban FGD : Ya alasan sama dengan jawaban wawancara.

7. Saya ingin memiliki alat olahraga. Jawaban kuesioner : bola voli $37 \%$. Jawaban wawancara :agar di saat berolahraga tidak tergantung pada fasilitas orang lain ataupun harus menyewa. Jawaban FGD : Ya benar bahwa mayoritas ingin sekali memiliki fasilitas olahraga bola voli terutama bolanya. 
8. Saya tertarik untuk melakukan jenis olahraga. Jawaban kuesioner : Kesehatan dan kebugaran 55\%.

9. Disekolah saya mengikuti ekstrakulikuler olahraga. Jawaban kuesioner : bola voli $41 \%$. Jawaban wawancara : sudah menjadi hobi dan juga menyalurkan kemampuan.Jawaban FGD :Sedikit tambahan bahwa para siswa paling antusias mengikuti ekstrakulikuler sepak bola dan futsal karena sangat sering diperlombakan antar sekolah.

10. Dilingkungan sekitar rumah saya tidak ada fasilitas olahraga. Jawaban kuesioner : Basket 83\%. Jawaban wawancara : Karena permainan basket tidak terlalu diminati oleh pemuda-pemuda di masyarakat. Jawaban FGD : Jawaban sama dengan hasil wawancara, namun sedikit tambahan bahwa selain olahraga yang kurang diminati, membuat lapangan basket juga membutuhkan biaya yang cukup besar sehingga jarang sekali kita melihat adanya lapangan basket dilingkungan sekitar rumah kecuali di sekolahan.

11. Saya tidak berminat berolahraga karena. Jawaban kuesioner : tidak ada waktu 43\%. Jawaban wawancara : Tidak ada waktu untuk berolahraga karena melakukan kegiatan lain. Jawaban FGD :Sebenarnya ada waktu saja untuk berolahraga baik itu di sore maupun malam hari, tergantung individu saja mengatur waktu untuk berolahraga. Kalau pelajar itu terbiasa berolahraga maka dia akan meluangkan waktunya untuk berolahraga.

12. Saya senang mempelajari materi tentang olahraga. Jawaban kuesioner : bola voli 42\%.Jawaban wawancara : Mayoritas pemuda senang mempelajari olahraga voli beralasan karena untuk menyalurkan hobi. Jwaban FGD : Jawaban sama dengan hasil kuesioner dan wawancara.

13. Saya senang mengajak teman atau keluarga untuk berolahraga. Jawaban kuesioner : bola voli 33\%. Jawaban wawancara : karena untuk mencari teman bertanding, agar menambah keseruan dalam berolahraga.Jawaban FGD : Jawaban sama dengan hasil kuesioner dan wawancara.

14. Saya senang berolahraga dengan teman karena. Jawaban kuesioner :Rame 57\%.

15. Saya senang melakukan aktivitas olahraga di. Jawaban kuesioner : sekolah $59 \%$. Jawaban wawancara : senang berolahraga disekolah karena banyak teman yang berolahraga sehingga menambah rame dan seru dalam berolahraga. Jawaban FGD : biasanya para siswa berolahraga di sekolah karena lapangan di balai desa di pakai oleh orang dewasa bermain.

16. Saya berolahraga karena untuk. Jawaban kuesioner : menjaga kebugaran $69 \%$.Jawaban wawancara : dengan berolahraga akan menjaga kebugaran tubuh, dengan berolahraga juga lemak didalam tubuh akan terbakar menjadi keringat sehingga akan mengurangi berat badan. Jawaban FGD : Jawaban sama dengan hasil kuesioner dan wawancara.

17. Saya ingin meningkatkan keahlian dalam olahraga. Jawaban kuesioner : bola voli $36 \%$. Jawaban wawancara : untuk menyalurkan hobi, ingin memiliki teknik yang baik dan benar, serta supaya lebih pandai memainkannya. Jawaban FGD : Jawaban sama dengan hasil kuesioner dan wawancara.

18. Disekitar rumah saya terdapat club olahraga. Jawaban kuesioner : bola voli $31 \%$. Jawaban wawancara : Dampak adanya club bagi pemudasangat besar, dengan adanya club tersebut para pemuda termotivasi untuk berolahraga, serta termotivasi untuk hebat dalam bermain olahraga tersebut agar mendapatkan prestasi. Jawaban FGD : Fakta yang terlihat saat ini bahwa banyak sekali club futsal. Karena sering diadakan pertandingan futsal. Selain itu juga bahwa usaha penyewaan lapangan futsal sudah berkembang di sekitar kota, sehingga skarang banyak lapangan futsal.

19. Saya senang berpartisipasi dalam perlombaan atau pertandingan olahraga. Jwaban kuesioner : bola voli $35 \%$. 
Jawaban wawancara : karena mencari pengalaman bertanding untuk menambah jam terbang bertanding. Jawaban FGD : Jawaban sama dengan hasil wawancara, namun sedikit tambahan bahwa di kota Palangkaraya pertandingan olahraga yang paling sering di adakan untuk pemuda yaitu olahraga futsal.

20. Dilingkungan saya sering mengadakan perlombaan atau pertandingan olahraga. Jawaban kuesioner : bola voli $49 \%$. Jawaban wawancara : Biasanya diadakan pertandingan pada waktu-waktu tertentu saja. Seperti HUT RI. Jawaban FGD : Jawaban sama dengan hasil wawancara, sedikit tambahan bahwa yang paling sering diadakan pertandingan antar sekolah yaitu olahraga futsal.

21. Saya tertarik terhadap olahraga. Jawaban kuesioner : bola voli 35\%. Jawabn wawancara : karena olahraganya seru dan rame. Jawaban FGD : Jawaban sama dengan hasil wawancara.

22. Dilingkungan sekitar saya ada fasilitas olahraga.Jawaban kuesioner : bola voli $56 \%$. Jawaban wawancara : Fasilitas olahraga yang ada disekitar rumah mayoritas berasal dari gotong royong masyarakat. Mereka bergotong royong membuat fasilitas olahraga agar ada kegiatan berolahraga disekitarnya setelah menjalani aktivitas lain.Jawaban FGD : Ya benar bahwa fasilitas yang hampir setiap RT ada yaitu lapangan voli yang berasal dari swadaya masyarakat dengan bergotong royong membuatnya.

23. Saya sering mengobrol dengan orang membahas masalah olahraga. Jawaban kuesioner : bola voli 38\%.

24. Yang selalu memotivasi saya untuk berolahraga adalah.Jawaban kuesioner : Pelatih/guru 41\%.

Jawaban wawancara : mereka mengatakan bahwa olahraga baik untuk kesehatan, selain itu juga dapat menjaga kebugaran tubuh serta untuk meraih prestasi yang dicita-citakan. Jawaban FGD : Jawaban sama dengan hasil kuesioner dan wawancara.
25. Saya suka terlibat dalam club olahraga.Jawaban kuesioner : bola voli 34\%.Jawaban wawancara : karena untuk mengasah dan mengembangkan kemampuan berolahraga.

Jawaban FGD : Jawaban sama dengan hasil wawancara.

26. Saya memiliki perlengkapan olahraga.Jawaban kuesioner : Bulu tangkis $28 \%$

27. Saya lebih suka berolahraga di waktu.Jawaban kuesiner : Sore hari 69\%. Jawaban wawancara : karena dipagi hari sekolah, selain itu berolahraga disore hari lebih santai karena waktu yang relatif panjang serta cuaca disore hari tidak panas. Jawaban FGD : Jawaban sama dengan hasil wawancara dan kuesioner.

28. Saya suka berolahraga sejak usia. Jawaban kuesioner : 9-12 thn 45\%. Jawban wawancara : mayoritas sampel memilih 9-12 tahun dengan alasan bahwa disaat jangka waktu usia tersebut sudah mengenal olahraga dari televisi, kemudian lingkungan sekitar yang mayoritas usia segitu sudah mulai berolahraga.Jawaban FGD : Jawaban sama dengan hasil wawancara. Sedikit tambahan bahwa anak usia 9-12 tahun merupakan masa aktif bagi anak-anak, sehingga usia sigitu merupakan usia yang tepat untuk lebih mengenal olahraga lebih mendalam.

Sampel bersuku Banjar

1. Saya senang menonton pertandingan olahraga. Jawaban kuesioner :Sepak bola $59 \%$. Jawaban wawancara : menonton sepak bola biasanya ditelevisi dan juga youtube.Jawaban FGD : Ya benar bahwa mayoritas menyukai menonton sepak bola di televisi. Apalagi saat ini setiap pekan ada pertandingan sepakbola yang mudah ditonton ditelevisi.

2. Saya selalu mengikuti perkembangan olahraga.Jawaban kuesioner : Bulu Tangkis 34\%. Jawaban wawancara : mengikuti perkembangan olahraga yang disukai karena menggemari serta ada pemain dan club favorit. Jawaban FGD : 
Jawaban sama dengan hasil kuesioner dan wawancara.

3. Setiap hari saya selalu ingin melakukan olahraga. Jawaban kuesioner : Bulu Tangkis 23\%. Jawaban wawancara : alasan senang bermain bulu tangkis karena rame, bermain team, menyenangkan. Jawaban FGD : banyak dari pemuda Banjar menyukai olahraga pencaksilat yang mereka namakan kesenian beladiri karena itu merupakan tradisi dari leluhur, dan sudah diperkenalkan oleh orang tua dari kecil dengan alasan ada unsur rohaninya beladiri tersebut.

4. Saya ingin menjadi atlet olahraga.Jawaban kuesioner : Sepak bola $26 \%$. Jawaban wawancara : alasan utama ingin menjadi atlet karena untuk membanggakan kedua orang tua dan menjadi terkenal.Jawaban FGD : Mayoritas pemuda banjar berolahraga itu karena hobi saja bukan untuk menjadi seorang atlet. Mereka lebih antusias menjadi seorang pedagang yang sukses dari pada seorang atlet karena sudah sejak remaja mereka sudah ditanamkan oleh kedua orang tuanya untuk berdagang.

5. Saya berolahraga dalam sehari minimal.Jawaban kuesioner : 20-40 menit $59 \%$.

6. Di lingkungan sekitar saya mayoritas melakukan aktivitas olahraga.

Jawaban kuesioner : Bulu tangkis 69\%. Jawaban wawancara :bermain bulu tangkis cukup didepan halaman rumah saja. Jawaban FGD : Jawaban sama dengan hasil kuesioner dan wawancara.

7. Saya ingin memiliki alat olahraga.Jawaban kuesioner : Sepak bola $24 \%$.

8. Saya tertarik untuk melakukan jenis olahraga.

Jawaban kuesioner : Kesehatan dan kebugaran 53\%.

9. Disekolah saya mengikuti ekstrakulikuler olahraga.Jawaban kuesioner : Tidak ikut $56 \%$. Jawaban wawancara : Lebih menyukai ekstrakulikuler di luar olahraga. Jawaban FGD : Jawaban sama dengan hasil kuesioner dan wawancara.

10. Dilingkungan sekitar rumah saya tidak ada fasilitas olahraga. Jawaban kuesioner : Basket 54\%. Jawaban wawancara : mayoritas tidak ada fasilitas olahraga basket disekitar rumah karena membutuhkan biaya yang banyak dan lahan yang cukup luas. Jawaban FGD : Jawaban sama dengan hasil kuesioner dan wawancara.

11. Saya tidak berminat berolahraga karena.Jawaban kuesioner : Tidak ada waktu 38\%.Jawaban wawancara : alasan tidak berminat berolahraga karena tidak ada waktu sebab disibukkan dengan sekolahbeserta tugas-tugasnya. Jawaban FGD : Jawaban sama dengan hasil kuesioner dan wawancara.

12. Saya senang mempelajari materi tentang olahraga.Jawaban kuesioner : Bulu tangkis 28\%. Jawaban wawancara : alasan senang mempelajari materi ini karena untuk menambah teknik baru dengan benar. Jawaban FGD :olahraga bulu tangkis yang lebih mudah dipelajarai dan bisa dimainkan semua kalangan.

13. Saya senang mengajak teman atau keluarga untuk berolahraga.Jawaban kuesioner : Bulutangkis 24\%. Jawaban wawancara :karena untuk membangun kebersamaan, menjaga pola hidup sehat dan menghilangkan beban pikiran.

Jawaban FGD : Jawaban sama dengan hasil kuesioner dan wawancara.

14. Saya senang berolahraga dengan teman karena,.Jawaban kuesioner : Rame 71\%.

15. Saya senang melakukan aktivitas olahraga di.Jawaban kuesioner : sekolah $62 \%$. Jawaban wawancara:fasilitas olahraga disekolah memadai sedangkan dirumah fasilitas minim. Jawaban FGD : Jawaban sama dengan hasil kuesioner dan wawancara.

16. Saya berolahraga karena untuk.Jawaban kuesioner : meningkatkan kebugaran 67\%. Jawaban wawancara : alasan lain berolahraga karena untuk menjaga kesehatan, kebugaran, daya tahan tubuh, mendapatkan teman baru, hiburan, 
meraih cita-cita, melatih ketangkasan, menjaga berat badan, menjaga daya tahan tubuh. Jawaban FGD : Jawaban sama dengan hasil kuesioner dan wawancara.

17. Saya ingin meningkatkan keahlian dalam olahraga.Jawaban kuesioner : Bulu tangkis 23\%. Jawaban wawancara : alasan ingin meningkatkan keahlian dalam bidang olaharaga karena untuk meningkatkan kemampuan dalam berolahraga.Jawaban FGD : Ya, keinginan untuk meningkatkan keahlian dalam berolahraga dikarenakan untuk meningkatkan kemampuan mereka dalam berolahraga.

18. Disekitar rumah saya terdapat club olahraga.Jawaban kuesioner : tidak ada club $46 \%$. Jawaban wawancara : Tidak ada club disekitarrumah karena memang tidak ada fasilitas olahraga yang tersedia serta antusias masyarakat dan pemuda terhadap olahraga kurang, mereka lebih fokus untuk bekerja dankegiatan lainnya.Jawaban FGD : Ya benar bahwa sedikit ada club di sekitar rumah, itupun sebenarnya jauh dari rumah juga.

19. Saya senang berpartisipasi dalam perlombaan atau pertandingan olahraga.Jawaban kuesioner : Tidak senang berpartisipasi 27\%.Jawaban wawancara : Tidak senang berpartisipasi dalam bertandingan olahraga karena tidak ada minat untuk menjadi seorang atlet.Jawaban FGD : jawaban sama dengan hasil kuesioner dan wawancara.

20. Dilingkungan saya sering mengadakan perlombaan atau pertandingan olahraga.Jawaban kuesioner : Tidak ada pertandingan olahraga 37\%.Jawaban wawancara : pertandingan olahraga yang sering diadakan antar RT yaitu bola voli, sepak bola yang biasanya diadakan disaat 17 Agustusan. Jawaban FGD : pertandingan atau perlombaan olahraga sangat jarang sekali diadaakan disekitar rumah.

21. Saya tertarik terhadap olahraga. Jawaban kuesioner : bulu tangkis 28\%. Jawaban wawancara : mayoritas tertarik terhadap olahraga karena olahraga itu menyenangkan dan seru.Jawaban FGD : Jawaban sama dengan hasil kuesioner dan wawancara.

22. Dilingkungan sekitar saya ada fasilitas olahraga

Jawaban kuesioner : Tidak ada fasilitas olahraga 47\%.Jawaban wawancara : Hanya lahan kosong aja yang biasanya digunakan untuk berolahraga.Jawaban

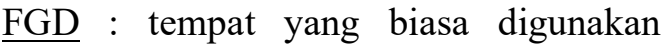
untuk berolahraga hanya berupa lahan kosong yang memiliki ukuran yang tidak cukup luas.

23. Saya sering mengobrol dengan orang membahas masalah olahraga.Jawaban kuesioner : Sepak bola 48\%. Jawaban Wawancara : Karena teman-teman disekolah suka ngobrol tentang sepak bola juga. Jawaban FGD : Jawaban sama dengan hasil kuesioner dan wawancara.

24. Yang selalu memotivasi saya untuk berolahraga adalah.Jawaban kuesioner : Pelatih/guru 43\%.

Jawaban wawancara : pelatih atau guru selalu memotivasi untuk selalu berolahraga supaya badan tetap bugar dan sehat.Jawaban FGD : jawaban sama dengan hasil kuesioner dan wawancara.

25. Saya suka terlibat dalam club olahraga.Jawaban kuesioner : Tidak suka ikut club $42 \%$.

Jawaban wawancara : mayoritas tidak ikut club karena disekitar rumah tidak ada club dan fasilitas olahraga yang tidak memadai.Jawaban FGD : Kebanyakan anak remaja sekarang suka terlibat dalam club olahraga futsal, sebab sering sekali diadakan pertandingan futsal antar pelajar.

26. Saya memiliki perlengkapan olahraga... Jawaban kuesioner : Bulu tangkis 39\%.

27. Saya lebih suka berolahraga di waktu.Jawaban kuesioner : Sore hari 49\%. Jawaban wawancara : Alasan menyukai olahraga di sore hari karena sore hari waktu yang pas buat berolahraga, ada waktu luang dan suasananya lebih santai. Jawaban FGD : Jawaban sama dengan hasil kuesioner dan wawancara. 
28. Saya suka berolahraga sejak usia.Jawaban kuesioner :> 12 tahun 44\%.Jawaban wawancara : disaat menginjak usia belasan tahun baru sadar dan mengerti bahwa berolahraga itu baik bagi kesehatan. Jawaban FGD : Usia belasan tahun merupakan usia yang sudah matang untuk memilih olahraga mana yang disukai dan digemari.

$\underline{\text { Sampel bersuku Jawa }}$

1. Saya senang menonton pertandingan olahraga. Jawaban kuesioner : Sepak bola $48 \%$.Jawaban wawancara : biasanya menonton pertandingan olahraga sepak bola di televisi.Jawaban FGD : Memang benar bahwa teman-teman lebih suka menontonsepak bola karena olahraga tersebut banyak di gemari.

2. Saya selalu mengikuti perkembangan olahraga.Jawaban kuesioner : Sepak bola $34 \%$. Jawaban wawancara : senang mengikuti perkembangan olahraga karena ada pemain idola dan club favorit, dan juga hobi.Jawaban FGD : Mereka senang menonton pertandingan olahraga tertentu karena hoby dengan olahraga tersebut, sehingga harus selalu update informasi untuk menambah wawasan.

3. Setiap hari saya selalu ingin melakukan olahraga.Jawaban kuesioner : Sepak bola $27 \%$. Hasil wawancara : Suka bermain sepak bola karena rame bisa bermain dengan teman2, dan dilingkungan rumah juga para pemudanya mayoritas menyukai olahraga sepak bola. Jawaban FGD : menyukai olahraga sepak bolakarena fasilitas yang memadai di balai desa dan gelanggang olahraga.

4. Saya ingin menjadi atlet olahraga.Jawaban kuesioner : Tidak ingin menjadi atlet $27 \%$. Jawaban wawancara :Tidak ada niat untuk menjadi seorang atlet. Jawaban FGD : Rata-rata pemuda di kampung berolahraga itu hanya untuk sebatas hobi dan menjaga kebugaran tubuh saja bukan untuk menjadi seorang atlet.

5. Saya berolahraga dalam sehari minimal.Jawaban kuesioner : 20-40 menit $40 \%$. Jawaban wawancara : terkadang tidak ada waktu utnuk berolahraga lebih lama karena harus mengerjakan aktivitas yang lain.Jawban FGD : Biasanya pemuda berolahraga \pm 60 menit, karena bagi mereka berolahraga itu mengasyikkan sehingga lupa dengan waktu.

6. Di lingkungan sekitar saya mayoritas melakukan aktivitas olahraga.Jawaban kuesioner: sepak bola 41\%. Jawaban wawancara : rata-rata pemuda suka dengan olahraga sepak bola, hal itu dikarenakan fasilitas yang cukup memadai untuk berolahraga walaupun tidak lengkap. Jawaban FGD :karena lapangan sepak bola yang memadai untuk bermain sepak bola.

7. Saya ingin memiliki alat olahraga.Jawaban kuesioner : bola voli $34 \%$.Jawaban wawancara : agar bisa berolahraga kapan saja tanpa harus tergantung dengan orang lain untuk berolahraga.

Jawaban FGD : alasan ingin memiliki alat olahraga sendiri agar bisa berlatih sendiri dirumah tanpa tergantung dengan alat olahraga orang lain.

8. Saya tertarik untuk melakukan jenis olahraga. Jawaban kuesioner : Kesehatan dan kebugaran61\%.

9. Disekolah saya mengikuti ekstrakulikuler olahraga. Jawaban kuesioner : Sepak bola $41 \%$. Jawaban wawancara :Mengikuti ekstarkulikuler sepak bola karena banyak peminatnya disekolah jadi terasa rame. Jawaban FGD : mayoritas menyukai ekstrakulikuler olahraga sepakbola karena fasilitas di sekolah cukup lengkap untuk bermain.

10. Dilingkungan sekitar rumah saya tidak ada fasilitas olahraga.Jawaban kuesioner : Basket $81 \%$. Jawaban wawancara : alasan tidak ada fasilitas basket di sekitar rumah karena membuat lapangan basket membutuhkan dana yang besar. Jawaban

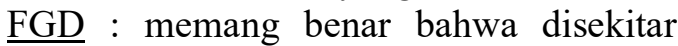
rumah tidak ada fasilitas olahraga basket, sebab olahraga basket tidak begitu diminati dikampung sehingga tidak ada inisiatif untuk membuat fasilitas basket. 
11. Saya tidak berminat berolahraga karena.Jawaban kuesioner : tidak ada waktu $37 \%$.

Jawaban wawancara : terkadang memang tidak berminat untuk berolahraga, hal itu disebabkan karena tidak ada waktu. Jawaban FGD : jawaban sama dengan hasil kuesioner dan FGD. Namun terkait dengan alasan tidak ada waktu utnuk berolahraga sebenarnya kurang setuju, sebenarnya ada saja waktu untuk berolahraga tergantung cara kita mengatur waktu saja.

12. Saya senang mempelajari materi tentang olahraga.Jawaban kuesioner : Sepak bola 42\%. Jawaban wawancara : karena untuk menambah teknik baru.Jawaban FGD : jawaban sama dengan hasil kuesioner dan wawancara.

13. Saya senang mengajak teman atau keluarga untuk berolahraga.Jawaban kuesioner : Sepak bola 35\%.Jawaban wawancara : karena untuk menghilangkan beban pikiran, agar lebih seru dan menambah keakraban.Jawaban FGD :karena olahraga simple dan mudah dilakukan dan juga menambah erat persaudaraan.

14. Saya senang berolahraga dengan teman karena. Jawaban kuesioner : Rame 74\%.

15. Saya senang melakukan aktivitas olahraga di.Jawaban kuesioner : Sekolah 33\%. Jawaban wawancara : karena lebih leluasa serta fasilitas cukup lengkap, selain itu berolahraga di sekolah juga musuhnya seumuran teman-teman sendiri. Jawaban FGD :jawaban sama dengan hasil kuesioner dan wawancara.

16. Saya berolahraga karena untuk.Jawaban kuesioner : menjaga kebugaran tubuh $74 \%$.

Jawaban wawancara : untuk menigkatkan kebugaran jasmani, melatih ketangkasan dan keberanian. Jawaban FGD : jawaban sama dengan hasil kuesioner dan wawancara.

17. Saya ingin meningkatkan keahlian dalam olahraga.Jawaban kuesioner : sepak bola $27 \%$. Jawaban wawancara : ingin meningkatkan keahlian dalam berolahraga agar lebih hebat lagi dari orang lain. Jawaban FGD : jawaban sama dengan hasil kuesioner dan wawancara.

18. Disekitar rumah saya terdapat club olahraga.

Jawaban kuesioner : tidak ada club 38\%. Jawaban wawancara :Jarang sekali ada club. Jawaban FGD : Memang didaerah setiap tempat tidak selalu ada club olahraga.

19. Saya senang berpartisipasi dalam perlombaan atau pertandingan olahraga.Jawaban kuesioner : Sepak bola $34 \%$. Jawaban wawancara : karena ingin meraih cita-cita menjadi atlet terkenal dan menambah pengalaman bertanding. Jawaban FGD : Jawaban sama dengan hasil kuesioner dan wawancara.

20. Dilingkungan saya sering mengadakan perlombaan atau pertandingan olahraga.Jawaban kuesioner : bola voli $42 \%$. Jawaban wawancara :Biasanya perlombaan diadakan untuk memperingati HUT RI yaitu 17 Agustus dilakukan di balai desa.

Jawaban FGD : Jarang sekali diadakan, namun setiap tahun ada pertandingan bola voli dan sepak bola antar RT dan RW pada 17 Agustus dalam rangka memperingati HUT RI.

21. Saya tertarik terhadap olahraga. Jawaban kuesioner : Sepak bola 30\%. Jawaban wawancara : karena menyenangkan dan seru, sebab dimainkan oleh banyak orang dalam satu pertandingan. Jawaban FGD : jawaban sama dengan hasil kuesioner dan wawancara.

22. Dilingkungan sekitar saya ada fasilitas olahraga.Jawaban kuesioner : bola voli $46 \%$.Jawaban wawancara : lapangan tersebut berasal dari swadaya atau gotong royong masyarakat atas inisiatif kepala desa.Jawaban FGD : Jawaban sama dengan hasil wawancara.

23. Saya sering mengobrol dengan orang membahas masalah olahraga. Jawaban kuesioner : Sepak bola 37\%.

24. Yang selalu memotivasi saya untuk berolahraga adalah.Jawaban kuesioner : Diri sendiri 27\%. 
Jawaban wawancara :Diri sendiri memotivasi untuk berolahraga karena ingin hidup sehat, sudah menjadi hobi pribadi.Jawaban FGD : Jawaban sama dengan hasil kuesioner dan wawancara.

25. Saya suka terlibat dalam club olahraga.Jawaban kuesioner : tidak suka ikut club 41\%. Jawaban wawancara : tidak suka terlibat dalam club karena club olahraga di sekitar rumah tidak ada.Jawaban FGD : memang benar bahwa tidak ikut dalam club karena disekitar rumah tidak ada club. Kalaupun ada club olahraga biasanya berlatihnya mendekati pertandingan saja yang diadakan oleh desa setiap tahun.

26. Saya memiliki perlengkapan olahraga. Jawaban kuesioner : sepak bola 30\%.

27. Saya lebih suka berolahraga di waktu.Jawaban kuesioner : sore hari 76\%. Jawaban wawancara : karena waktunya senggang, tidak panas, lebih santai karena waktu yang relatif panjang.Jawaban FGD : Jawaban sama dengan hasil wawancara.

28. Saya suka berolahraga sejak usia.Jawaban kuesioner : 9-12 tahun 43\%. Jawaban wawancara : mayoritas menyukai olahraga sejak usia 9-12 tahun sebab waktu kecil kurang suka olahraga, sudah paham tentang olahraga umur segitu. Jawaban FGD : Alasan mayoritas suka berolahraga sejak usia 9-12 tahun, karena usia segitu sudah paham bakat di olahraga.

\section{PEMBAHASAN.}

Dalam penelitian yang mengambil subjek partisipan tiga suku bangsa ini, terdapat beberapa perbedaan partisipasi berolahraga mereka dalam kehidupan sehari-hari. Penelitian ini juga telah berhasil mengungkapkan mengenai minat berpartisipasi dalam berolahraga ketiga suku bangsa tersebut berdasarkan beberapa kriteria yaituperasaan senang, keterlibatan, ketertarikan, dan perhatian.

Adapun penjelasannya dipaparkan sebagai berikut :

\section{Perasaan Senang}

Suku Dayak lebih senang melakukan aktivitas olahraga Bolavoli yang biasa mereka lakukan di rumah maupun disekolah.
Selain itu, kesenangan mereka terhadap olahraga Bolavoli tersebut menjadikan mereka termotivasi untuk senang pula dalam menonton pertandingan dan mengikuti prekembangan olahraga Bolavoli. Tidak hanya sampai disitu, ternyata suku Dayak juga lebih senang berpartisipasi dalam pertandingan olahraga Bolavoli daripada olahraga lainnya.

Sesuatu yang menarik peneliti temukan disaat penelitian, bahwa menurut data penelitian mayoritas masyarakat bersuku Dayak itu bisa berenang. Sebab mayoritas diantara mereka memilih bertempat tinggal dipinggiran sungai. Sehingga rutinitas mereka dalam sehari-hari seperti MCK pun banyak mereka lakukan di sungai.

Namun lain halnya dengan suku Banjar, mereka lebih senang melakukan aktivitas olahraga bulutangkis yang mayoritas mereka lakukan disekolah karena fasilitas lebih memadai dari pada disekitar rumah. Adapun aktivitas olahraga dirumah biasa mereka lakukan di lahan kosong. Hal ini perlu kita maklumi karena daerah sekitar tempat tinggal mereka sudah tidak ada lagi tanah umum untuk pembangunan fasilitas olahraga.

Sisi menarik dari masyarakat suku Banjar dari segi olahraga adalah bahwa mereka lebih condong kepada olahraga yang ada unsur religius atau rohaninya. Berdasarkan hasil penelitian bahwa kesenian bela diri merupakan salah satu yang digemari. Sebab mereka berlandaskan bahwa beladiri merupakan olahraga yang bukan hanya ada unsur jasmani saja namun ada juga unsur rohaninya. Selain itu, secara turun-temurun orang tua juga sering bercerita kepada anakanaknya tentang kelebihan-kelebihan seni bela diri dari olahraga lainnya.

Begitu juga dengan mereka yang bersuku Jawa, sepakbola merupakan aktivitas olahraga yang senang mereka lakukan disetiap harinya. Hal itu dapat dilihat dari hasil temuan angket bahwa mayoritas memilih senang menonton dan mengikuti perkembangan olahraga sepakbola. Namun kesenangan mereka melakukan olahraga sepakbola disetiap harinya, belum bisa mereka keluarkan dalam event pertandingan besar. Karena menurut 
hasil data penelitian bahwa mayoritas tidak menyukai untuk ikut pertandingan olaraga karena beralasan sangat jarang dilaksanakan pertadingan olahraga kecuali hari-hari besar saja.

Disisi lain, mayoritas pemuda Jawa disana juga menyukai olahraga pencak silat. Pencak silat mereka sukai karena menurut mereka pencak silat dapat dijadikan sebagai pegangan dan modal untuk melindungi diri sendiri dari kejahatan orang lain. Hal ini disebabkan karena didaerah perkampungan mereka masih sering terjadi kejahatan dikarenakan daerah yang masih relatif sepi pada tempat-tempat tertentu.

Kalau kita cermati pembahasan diatas, maka dapat disimpulkan bahwa setiap suku memiliki keinginan dan alasan yang berbeda dalam melakukan aktivitas olahraga. Seperti apa yang dikatakan oleh Yan dan McCullagh (2004) meneliti tentang pengaruh budaya terhadap motivasi partisipasi pemuda dalam aktivitas fisik. Hasil dari penelitian tersebut menyatakan bahwa pemuda yang berbeda sosial budayanya akan berbeda pula keinginan dan dorongan untuk berpartisipasi dalam aktivitas olahraga.

Keterlibatan

Suku Dayak lebih suka terlibat dalam olahraga Bolavoli dari pada olahraga lainnya. Hal itu dapat kita lihat dari data bahwa mayoritas diantara mereka lebih memilih mengikuti ekstrakulikuler olahraga Bolavoli disekolah daripada olahraga lainnya. Waktu rata-rata mereka setiap kali berolahraga juga dibilang cukup tinggi. Karena setiap kali mereka berolahraga berdurasi 20-40 menit. Namun dari sekian motivasi dan minat dalam berolahraga, ada kalanya individu menemui kejenuhan dan tidak minat terhadap sesuatu. Ketidakminatan mereka terhadap olahraga terkadang dikarenakan tidak ada waktu untuk berolahraga karena melakukan kegiatan lain, dan juga terkadang tidak berolahraga karena badan sedang kurang fit.

Pada suku Banjar data penelitian menunjukkan bahwa lebih dari $50 \%$ tidak mengikuti ekstrakulikuler olahraga di sekolah, namun mereka lebih memilih ekstrakulikuler pengembangan diri diluar olahraga. Hal ini menunjukkan bahwa keterlibatan mereka terhadap aktivitas olahraga cukup rendah, sebab mereka mayoritas lebih memilih ekstrakulikuler non olahraga.

Namun jikalau dilihat dari segi waktu rata-rata mereka sekali melakukan aktivitas olahraga berdurasi 20-40 menit. Durasi tersebut bisa dikatakan cukup untuk melakukan aktivitas seklai berolahraga. Dari motivasi mereka dalam melakukan aktivitas olahraga, namun terkadang juga ada ketidakminatan mereka terhadap oahraga.

Siswa bersuku Jawa memiliki keterlibatan olahraga yang cukup tinggi di sekolahan. Mayoritas diantaranya terlibat dalam ekstrakulikuler olahraga Bolavoli. Hal ini terjadi karena pihak sekolah memfasilitasi olahraga begitu lengkap, sehingga para siswa merasa nyaman berolahraga dengan fasilitas yang legkap. Namun keterlibatan mereka dalam club cukup kecil, hal itu terjadi karena minimnya clu yang berada disekitar rumah mereka. Dilihat dari rata-rata waktu yang digunakan dalam sekali berolahraga hampir sama dengan suku bangsa lainnya yaitu berdurasi sekitar 20-40 menit.

$\underline{\text { Ketertarikan }}$

Tujuan mayoritas siswa bersuku Dayak melakukan aktivitas olahraga karena mereka menyadari bahwa dengan berolahraga akan menjaga kebugaran tubuh. Serta dengan berolahraga juga lemak didalam tubuh akan terbakar menjadi keringat sehingga akan mengurangi berat badan. Selain itu alasan berolahraga karena ingin mengisi waktu luang, sebagai hiburan agar otak kembali tenang. Tidak hanya itu saja, tujuan berolahraga bisa juga dikarenakan ingin meraih cita-cita menjadi atlet sukses.

Siswabersuku Banjar berolahraga itu karena untuk menyalurkan hobi dan menjaga kebugaran tubuh saja bukan untuk menjadi seorang atlet. Mereka lebih antusias dimasa mendatang menjadi seorang pedagang yang sukses dari pada seorang atlet karena sejak dini sudah ditanamkan oleh kedua orang tuanya untuk berdagang. Berdagang sudah dianggap tradisi.

Senada dengan alasan lainnya bahwa mayoritas pemuda Jawa menjawab 
berolahraga karena untuk menjaga kebugaran jasmani, melatih ketangkasan dan juga keberanian. Yang biasa mereka lakukan olahraga tesebut di waktu sore hari, dengan alasan bahwa sore hari merupakan waktu yang relatif panjang untuk digunakan dalam berolahraga. Terlebih mayoritas diantaranya bertempat tinggal di daerah Transmigrasi, sehingga kemampuan untuk melindungi diri dari kejahatan orang lain perlu dimiliki dikarenakan kondisi perkampungan yang masih belum rame.

Perhatian

Berdasarkan data hasil penelitian bahwa mayoritas fasilitas olahraga cukup memadai pada daerah tertentu tetapi tidak memadai pada daerah lainnya. Sebut saja seperti apa yang telah dihasil dalam penelitian ini, bahwa daerah Transmigrasi yang mayoritas bersuku Jawa dan daerah yang bersuku Dayak fasilitas olahraganya memadai. Fasilitas itu diantaranya lapangan Bolavoli dan sepakbola, dimana fasilitas tersebut hasil dari swadaya atau gotong royong masyarakat yang terletak di dekat balai desa setempat.

Namun berbeda dengan daerah pertokoan pasar yang mayoritas bersuku Banjar, disana fasilitas olahraga sangat terbatas. Bahkan biasanya mereka melakukan olahraga seperti sepakbola dan bulu tangkis dilahan kosong yang ada di sekitarnya. Kalaupun mereka menginginkan untuk berolahraga di lapangan olahraga yang memadai, maka harus pergi ke sport center yang letaknya lumayan jauh dari rumah mereka.

Selain fasilitas olahraga, penunjang motivasi pemuda untuk melakukan aktivitas olahraga yaitu adanya kegiatan perlombaan atau pertandingan olahraga yang dilakukan secara rutin. Hal tersebut akan merangsang pemuda untuk melakukan aktivitas olahraga. Dari hasil penelitian menunjukkan bahwa pertandingan atau perlombaan jarang diadakan. Baik itu hasil dari penelitian pada suku Dayak, Banjar maupun Jawa. Biasanya pertandingan olahraga dilakukan hanya pada hari-hari besar tertentu saja, seperti memperingati HUT Kemerdekaan RI yang biasanya perlombaan tersebut dilakukan pada bulan Agustus.
Tidak cukup sampai disitu saja bahwa orang-orang terdekat harus selalu memotivasi agar anak-anaknya rajin berolahraga untuk mendapatkan tubuh sehat dan bugar. Hasil dari penelitian ini juga menggambarkan bahwa, diantara ketiga suku diatas sepakat bahwa yang selalu memotivasi untuk melakkan aktivitas olahraga adalah orangorang terdekat mereka. Seperti kedua orang tua, pelatih dan guru.

Dari sekian penjelasan hasil penelitian diatas, disimpulkan bahwa budaya dapat mempengaruhi partisipasi seseorang dalam melakukan aktivitas olahraga dalam kehidupan sehari-hari.

\section{KESIMPULAN}

Berdasarkan hasil penelitian menunjukkan bahwa :

1. Siswa yang bersuku Dayak lebih menyukai berpartisipasi dalam olahraga bolavoli. Selain itu renang merupakan olahraga rutin dalam sehari-hari karena tempat tinggal mereka yang berada di pinggiran sungai.

2. Siswa yang bersuku Banjar lebih menyukai berpartisipasi dalam olahraga bulutangkis. Karakter suku Banjar yang agamis menjadikan mereka juga suka terhadap olahraga yang ada unsur religius atau rohaninya yaitu kesenian beladiri.

3. Siswa yang bersuku Jawa lebih menyukai berpartisipasi dalam olahraga sepakbola. Selain itu olahraga pencak silat juga disukai, sebab menurut mereka olahraga tersebut dapat dijadikan sebagai pegangan dan modal untuk melindungi diri sendiri dari kejahatan orang lain.

4. Secara umum suku Dayak, Banjar dan Jawa memilih melakukan olahraga tertentu dikarenakan adanya pengaruh lingkungan sosial dan budaya yang ada disekitar mereka.

\section{DAFTAR PUSTAKA}

Allender. S,.Cowburn. G,. Foster. C. (2006). Understanding participation in sport and physical activity among children and adults: A review of qualitative studies. Journal health education research., Vol.21 No.6 Pages 830.

Barber. H., Sukhi, H., White. S., A. (1999).The influence of parent-coaches 
on participant motivation andcompetitive anxiety in youth sport participants.Journal of sport behavior22(2), 162.

Fattahi, M.F., Masrur, F.F., Hossini, R. N. S., dan Mousavi, S. A. (2014). Analysis of preventive and motivating factors of students' participation in extracurricular sports programs.International journal of sport studies. Vol., 4 (3), 343.

Gungor, D., Bornstein, M.H., Leeersnyder, J.D., Cote, L., Ceulemans, E., andMesquita, B. (2012). Acculturation of personality:A Three-culture study ofjapanese, japanese americans,and european americans. Journal of crosscultural psychology.vol. 44 no. 5, 701.

Hepper. E. G., Sedikides. C., Cai. H. (2013). Self-enhancement and self-protection strategies in china: cultural expressions of a fundamental human motive. Journal of cross-cultural psychology.44 (1) 23.

Herdiansyah, Haris. 2013. Wawancara, observasi, dan focus group sebagai instrumen penggalian data kualitatif. Jakarta: Rajawali Pers

Herusatoto, B. (2005). Simbolisme dalam budaya jawa. Yogyakarta: PT. Hanindita Graha Widya

Kondric.M., Sindik.J., Mandic.G., F., Schiefler.B. (2013).Participation motivation and student's physical activity among sport studentsin three countries.Journal of sports science and medicine.12,117.

Lages, L.F., Abrantes, J.L., Seabra, C. (2007). Pedagogical affect, student interest, and learning performance.Journal of business research.Vol. 60.Hal. 964.

Maksum, A. (2012). Metodologi penelitian dalam olahraga.Surabaya : Unesa University Press.

Ncube, L. (2014). The interface between football and ethnic identity discourses in Zimbabwe. Critical african studies, Vol.6, Nos.2-3, 192.

Park, S. R. (2005). A cross-cultural study of the motivational factors affecting individuals' decision about participating in action sports between korean college students and their american counterparts. International journal of eastern sports \& physical education, 3(1), 3.

Slameto.(2010). Belajar dan faktor-faktor yang mempengaruhi.Jakarta: Rineka Cipta.

Subramaniam, P., R. (2009). Motivational effects of interest on student engagement and learning in physical education: A review. Journal physical education. Vol. 46(2).

Sugiyono. (2012). Metode penelitian kombinasi (mixed methods). Bandung: Alfabeta.

Sugiyono. (2012). Metodologi penelitian pendidikan (pendekatan kuantitatiff, kualitatif dan $R \& D)$. Bandung. CV. Alfabeta.

Yan, J.H., McCullagh. (2004). Cultural influence on youth's motivation of participation in physical activity. Journal of sport behavior, Vol. 27 Issue 4, p378.

Zacheus.T. (2010). The significance of sport and physical activity during the acculturation and integration process of immigrants in Finland - the experts' view, European journal for sport and society, 7 (2), 166.

Zahariadis, P.N., \& Biddle, S.J.H. (2000). Goal orientations and participation motives in physical education and sport: Their relationships in English schoolchildren. The online journal of sport psychology, Volume 2, Issue 1.

Zhu, X., Chen, A., Ennis, C. D., Sun, H., Hopple, C., Bonello, M., Bae, M., \& Kim, S. (2009). Situational interest, cognitive engagement, and learning achievement in physical education.Contemporary educational psychology, 34(3), 221. 